\title{
Increased frequency of Mediterranean fever gene variants in multiple myeloma
}

\author{
SERKAN CELIK $^{1}$, FATIH TANGI ${ }^{2}$ and CAGATAY OKTENLI ${ }^{3}$ \\ Divisions of ${ }^{1}$ Oncology and ${ }^{2}$ Internal Medicine, GATA Haydarpasa Training Hospital, Istanbul; \\ ${ }^{3}$ Department of Internal Medicine, Anadolu Medical Center, Kocaeli, Turkey
}

Received November 13, 2013; Accepted July 1, 2014

DOI: $10.3892 / 01.2014 .2407$

\begin{abstract}
High frequencies of inherited variants in the Mediterranean fever $(M E F V)$ gene have been identified in patients with multiple myeloma (MM). The sample size of the present pilot study was small, therefore, the actual frequency of inherited variants in the $M E F V$ gene could be investigated in patients with MM. Twenty-eight patients with $\mathrm{MM}$ and 65 healthy controls were included in the study. Six heterozygous and one homozygous (E148Q/E148Q) variant was identified in patients with MM. None of the patients had a family history compatible with familial Mediterranean fever. In the healthy control group, 11 heterozygous variants were identified. The difference in the overall frequency of the inherited variants in the $M E F V$ gene between the MM patients and the controls was statistically significant $\left(\chi^{2}=4.905 ; \mathrm{P}=0.027\right)$. In conclusion, a high frequency of inherited variants in the $M E F V$ gene was identified in patients with MM. Based on the current data, it is hypothesized that the $M E F V$ gene is a cancer susceptibility gene. Additional evidence, such as familial aggregation, monozygotic versus dizygotic twin concordance, and tumors in genetically engineered model organisms, is required in order to support this hypothesis.
\end{abstract}

\section{Introduction}

Familial Mediterranean Fever (FMF) is the most common Mendelian autoinflammatory disorder, which is characterized by recurrent attacks of fever with peritoneal, pleural or synovial inflammation (1-4). Missense mutations in the Mediterranean fever $(M E F V)$ gene have been shown to be causative of the disease (5). The 781-aa protein product of $M E F V$, denoted pyrin (also known as marenostrin) is produced in neutrophils, dendritic cells, eosinophils, monocytes, and synovial

Correspondence to: Professor Cagatay Oktenli, Department of Internal Medicine, Anadolu Medical Center, Cumhuriyet Mahallesi 2255 Sokak No. 3 Gebze, Kocaeli TR-41400, Turkey

E-mail: cagatay.oktenli@anadolusaglik.org; coktenli@yahoo.com

Key words: $M E F V$ gene, multiple myeloma, nuclear factor- $\kappa \mathrm{B}$, interleukin-1 $\beta$ fibroblasts (6-10). Currently, $>270$ inherited variants and polymorphisms in $M E F V$ have been reported in the Infevers Database (http://fmf.igh.cnrs.fr/ISSAID/infevers). Most of the inherited variants in $M E F V$ are located in exon 2 and 10 of the transcript (11). Pyrin contains several domains, including a pyrin domain (12-14), which is involved in homotypic protein-protein interactions in inflammatory and apoptotic signaling pathways $(7,15)$. Although the underlying mechanism is still being investigated, pyrin potentially plays a role in the modulation of interleukin-1 $\beta$ (IL-1 $\beta$ ) and nuclear factor- $\kappa \mathrm{B}$ $(\mathrm{NF}-\kappa \mathrm{B})(16-20)$. Any inherited variants in the $M E F V$ gene may cause inflammation and apoptosis due to the altered control of pyrin in the activation of IL-1 $\beta$ and NF- $\kappa B(21,22)$.

Multiple myeloma (MM) is a neoplastic plasma-cell disorder that is characterized by the aberrant expansion of monotypic plasma cells within the bone marrow $(23,24)$. Perturbed signaling pathways that control normal physiological processes, and mutations in several protooncogenes and tumor suppressor genes, can lead to the development of MM (23). Although NF- $\mathrm{B}$ functions in the pathogenesis of MM $(25,26)$, whether inherited variants in MEFV can lead to constitutive NF- $x$ B activation and cause a tendency for $\mathrm{MM}$ remains to be determine. Accumulated evidence has shown that there is a high frequency of inherited variants in $M E F V$ in patients with hematological malignancies as compared with the general population (27-31). This association has been included in the Genetic Association Database, Record 704091 (http://geneticassociationdb.nih. gov/cgi-bin/view.cgi?table=allview\&id=704091). In one of our previous studies, an increased frequency of inherited variants in $M E F V$ in patients with MM was observed (28). Since the sample size was small in the present pilot study, the actual frequency of inherited variants in $M E F V$ in patients with MM was able to be investigated.

\section{Materials and methods}

Subjects. Twenty-eight (17 male and 11 female) patients with MM and 65 healthy controls (40 male and 25 female) were included in the study. FMF patients or subjects who had a family history of FMF were excluded. The study protocol conformed to the ethical guidelines of the Helsinki Declaration. Informed consent was obtained from all patients and controls. The local Ethics Committee and Institutional Review Board 
approved the study. All the patients donated $2 \mathrm{ml}$ of blood, collected in an ethylenediaminetetraacetic acid tube. The eight inherited variants in the MEFV gene (M694I, M694V, M680I (G/C-A), V726A, R761H, E148Q and P369S) were detected using the Dr. Zeydanli ${ }^{\circledR}$ FMF Type I PCR system (Ankara, Turkey) 5' nuclease assay method using an ABI 7500 (Applied Biosystems, Foster City, CA, USA) quantitative polymerase chain reaction system, as previously reported (27).

Statistical analysis. Data were analyzed using SPSS 17.0 (SPSS Inc., Chicago, IL, USA) statistical software. Differences between the groups were analyzed using a $\chi^{2}$ test. $\mathrm{P} \leq 0.05$ was considered to indicate a statistically significant difference.

\section{Results}

The mean age of the patients with MM and healthy controls was $59.38 \pm 22.88$ years (age range, $32-84$ ) and $30.25 \pm 10.62$ years (age range, 20-45), respectively. Hematological characteristics and identified $M E F V$ gene variants in patients with MM are shown in Table I. Six heterozygous and one homozygous (E148Q/E148Q) variant in patients with MM was identified. None of the subjects had a family history compatible with FMF. In the healthy control group, 11 heterozygous variants were identified. M680I, M694I and R761H inherited MEFV gene variants were not found in any of the groups. The P369S variant was found in one healthy control.

Analytical data concerning the overall inherited $M E F V$ variant frequency between patients with $\mathrm{MM}$ and comparisons with healthy controls are given in Table II. The difference in the overall frequency of the inherited variants in the $M E F V$ gene between MM patients and the controls was statistically significant $\left(\chi^{2}=4.905 ; \mathrm{P}=0.027\right)$. When the distribution was compared between the patients and the controls, the frequency of the E148Q variant was significantly higher in the patient group as compared with the controls $\left(\chi^{2}=7.438 ; \mathrm{P}=0.006\right)$, while the M694V was significantly higher in the control group than MM patients $\left(\chi^{2}=5.658 ; \mathrm{P}=0.017\right)$.

\section{Discussion}

In the current study, a high frequency of inherited variants in the $M E F V$ gene was identified in patients with MM as compared with the healthy controls. These results are in concordance with our previous study (28). Of note, E148Q is the predominant inherited $M E F V$ variant in patients with MM. Pyrin, the protein product of the $M E F V$ gene, functions in the modulation of IL-1 $\beta$ and NF- $\kappa$ B. Since IL-1 $\beta$ is important for the anti-tumor immune response, it has been speculated that genetic variations that modify the expression of IL- $1 \beta$ may influence the risk of MM (32). NF- $\mathrm{KB}$ is another important transcription factor for the expression of genes critical for tumor promotion, cell proliferation, inflammation, metastasis, angiogenesis, and suppression of apoptosis (33). The function of NF- $\mathrm{KB}$ in lymphopoiesis is well recognized and it is an important factor for the regulation of cellular homeostasis of $\mathrm{T}$ and B lymphocytes (34-36). Altered NF- $\mathrm{kB}$ activation may cause an increased production of cell cycle regulatory and antiapoptotic proteins and may contribute to the abnormal proliferation and survival of neoplastic cells (37-39). It has

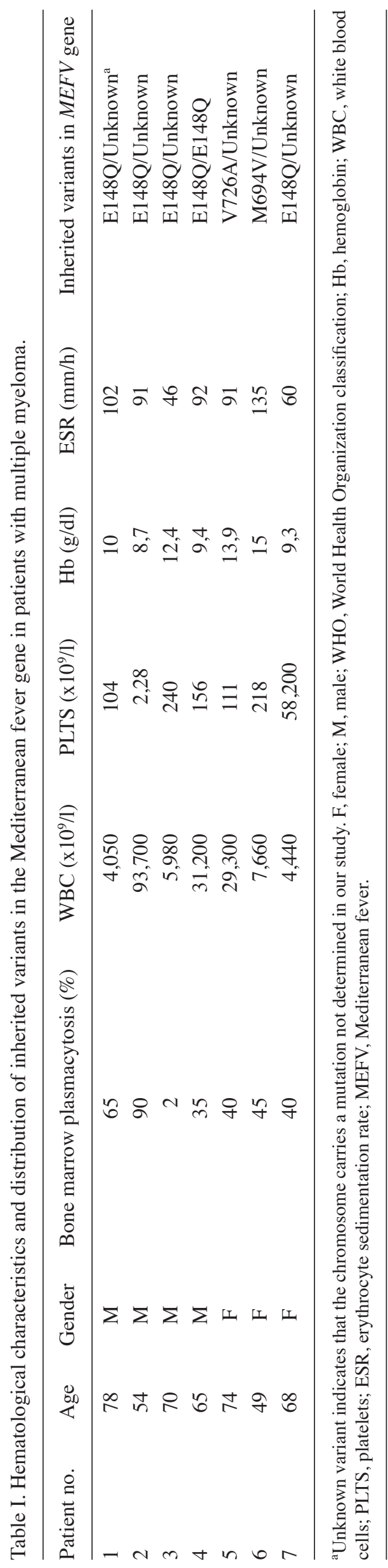


been reported that the $\mathrm{NF}-\kappa \mathrm{B}$ signaling pathway is critical in myeloma cell proliferation and the inhibition of apoptosis (40). Furthermore, constitutive nuclear $\mathrm{NF}-\kappa \mathrm{B}$ activity has been reported in numerous human $\mathrm{MM}$ cell lines and primary myeloma cells $(41,42)$. Specifically, as a distinct mechanism, constitutive activation in the $\mathrm{NF}-\kappa \mathrm{B}$ signaling pathway or blockade of IL-1 $\beta$ secretion due to defective pyrin may be associated with an increased frequency of inherited $M E F V$ variants in patients with MM.

The present study has some limitations. Firstly, only eight inherited variants in the $M E F V$ gene were screened in the patients. Rare or novel variants therefore have not been identified. Secondly, the family members of the patients included in this study were not screened for the inherited $M E F V$ variants. However, the individual and family history for FMF manifestations was negative in these subjects.

In conclusion, a high frequency of inherited $M E F V$ gene variants was shown to be associated with MM. Based on the current data, it may be hypothesized that the $M E F V$ gene is a cancer susceptibility gene. Additional evidence, such as familial aggregation, monozygotic versus dizygotic twin concordance and analysis of tumors in genetically-engineered model organisms, is required in future studies.

\section{References}

1. Celik S, Oktenli C, Terekeci HM, et al: Blood oxidative stress biomarkers in patients with familial Mediterranean fever. Akt Rheumatol 35: 382-385, 2010.

2. Terekeci HM, Oktenli C, Ozgurtas T, et al: Increased asymmetric dimethylarginine levels in young men with familial Mediterranean fever (FMF): is it early evidence of interaction between inflammation and endothelial dysfunction in FMF? J Rheum 35: 2024-2029, 2008.

3. Terekeci HM, Ulusoy ER, Kucukarslan NM, Nalbant S and Oktenli C: Familial Mediterranean fever attacks do not alter functional and morphologic tissue Doppler echocardiographic parameters. Rheum Int 28: 1239-1243, 2008.

4. Musabak U, Sengul A, Oktenli C, et al: Does immune activation continue during an attack-free period in familial Mediterranean fever? Clin Exp Immunol 138: 526-533, 2004.

5. Chae JJ, Cho YH, Lee GS, et al: Gain-of-function Pyrin mutations induce NLRP3 protein-independent interleukin-1 $\beta$ activation and severe autoinflammation in mice. Immunity 34 : 755-768, 2011.

6. Koc B, Oktenli C, Bulucu F, et al: The rate of pyrin mutations in critically ill patients with systemic inflammatory response syndrome and sepsis: a pilot study. J Rheumatol 34: 2070-2075, 2007.

7. Centola M, Aksentijevich I and Kastner DL: The hereditary periodic fever syndromes: molecular analysis of a new family of inflammatory diseases. Hum Mol Genet 7: 1581-1588, 1998.

8. Diaz A, Hu C, Kastner DL, et al: Lipopolysaccharide-induced expression of multiple alternatively spliced MEFV transcripts in human synovial fibroblasts: a prominent splice isoform lacks the C-terminal domain that is highly mutated in familial Mediterranean fever. Arthritis Rheum 50: 3679-3689, 2004.

9. French FMF Consortium: A candidate gene for familial Mediterranean fever. Nat Genet 17: 25-31, 1997.

10. The International FMF Consortium: Ancient missense mutations in a new member of the RoRet gene family are likely to cause familial Mediterranean fever. Cell 90: 797-807, 1997.

11. Touitou I: The spectrum of Familial Mediterranean Fever (FMF) mutations. Eur J Hum Genet 9: 473-483, 2001.

12. Bertin J and DiStefano PS: The PYRIN domain: a novel motif found in apoptosis and inflammation proteins. Cell Death Differ 7: 1273-1274, 2000.

13. Martinon F, Hofmann $\mathrm{K}$ and Tschopp J: The pyrin domain: a possible member of the death domain fold family implicated in apoptosis and inflammation. Curr Biol 11: R118-R120, 2001. 
14. Schaner P, Richards N, Wadhwa A, et al: Episodic evolution of pyrin in primates: human mutations recapitulate ancestral amino acid states. Nat Genet 27: 318-321, 2001.

15. Srinivasula SM, Poyet JL, Razmara M, et al: The PYRIN-CARD protein ASC is an activating adaptor for caspase-1. J Biol Chem 277: 21119-21122, 2002.

16. Chae JJ, Wood G, Richard K, et al: The familial Mediterranean fever protein, pyrin, is cleaved by caspase-1 and activates NF-kappaB through its N-terminal fragment. Blood 112: 1794-1803, 2008.

17. Fernandes-Alnemri T, Wu J, Yu JW, et al: The pyroptosome: a supramolecular assembly of ASC dimers mediating inflammatory cell death via caspase-1 activation. Cell Death Differ 14: 1590-1604, 2007.

18. ManjiGA, WangL, Geddes BJ, et al: PYPAF1,aPYRIN-containing Apaf1-like protein that assembles with ASC and regulates activation of NF-kappa B. J Biol Chem 277: 11570-11575, 2002.

19. Matsushita K, Takeoka M, Sagara J, et al: A splice variant of ASC regulates IL-1beta release and aggregates differently from intact ASC. Mediators Inflamm 2009: 287387, 2009.

20. Stehlik C, Fiorentino L, Dorfleutner A, et al: The PAAD/ PYRIN-family protein ASC is a dual regulator of a conserved step in nuclear factor kappaB activation pathways. J Exp Med 196: 1605-1615, 2002.

21. Papin S, Cuenin S, Agostini L, et al: The SPRY domain of Pyrin, mutated in familial Mediterranean fever patients, interacts with inflammasome components and inhibits proIL-1beta processing. Cell Death Differ 14: 1457-1466, 2007.

22. Stojanov S and Kastner DL: Familial autoinflammatory diseases: genetics, pathogenesis and treatment. Curr Opin Rheumatol 17: 586-599, 2005

23. Hallek M, Bergsagel PL and Anderson KC: Multiple myeloma: increasing evidence for a multistep transformation process Blood 91: 3-21, 1998.

24. Li ZW, Chen H, Campbella RA, Bonavidab B and Berensona JR: NF-kappaB in the pathogenesis and treatment of multiple myeloma. Curr Opin Hematol 15: 391-399, 2008.

25. Annunziata CM, Davis RE, Demchenko Y, et al: Frequent engagement of the classical and alternative NF-kappaB pathways by diverse genetic abnormalities in multiple myeloma. Cancer Cell 12: 115-130, 2007.

26. Keats JJ, Fonseca R, Chesi M, et al: Promiscuous mutations activate the noncanonical NF-kappaB pathway in multiple myeloma. Cancer Cell 12: 131-144, 2007.

27. Oktenli C, Sayan O, Celik S, et al: High frequency of MEFV gene mutations in patients with myeloid neoplasm. Int J Hematol 91: 758-761, 2010

28. Celik S, Erikci AA, Tunca Y, et al: The rate of MEFV gene mutations in hematolymphoid neoplasms. Int J Immunogenet 37 387-391, 2010
29. Sayan O, Kilicaslan E, Celik S, et al: High frequency of inherited variants in the MEFV gene in acute lymphocytic leukemia. Indian J Hematol Blood Transfus 27: 164-168, 2011.

30. Celik S, Oktenli C, Kilicaslan E, et al: Frequency of inherited variants in the MEFV gene in myelodysplastic syndrome and acute myeloid leukemia. Int J Hematol 95: 285-290, 2012.

31. Oktenli C and Celik S: High frequency of inherited variants in the MEFV gene in patients with hematologic neoplasms: a genetic susceptibility? Int J Hematol 95: 380-385, 2012.

32. Vangsted AJ, Nielsen KR, Klausen TW, et al: A functional polymorphism in the promoter region of the IL-1B gene is associated with risk of multiple myeloma. Br J Haematol 158: 515-518, 2012.

33. Hanahan D and Weinberg RA: The hallmarks of cancer. Cell 100: 57-70, 2000.

34. Bottero V, Withoff S and Verma IM: NF-kappaB and the regulation of hematopoiesis. Cell Death Differ 13: 785-797, 2006.

35. Grossmann M, Metcalf D, Merryfull J, et al: The combined absence of the transcription factors Rel and RelA leads to multiple hemopoietic cell defects. Proc Natl Acad Sci USA 96: 11848-11853, 1999.

36. Siebenlist U, Brown K and Claudio E: Control of lymphocyte development by nuclear factor-kappaB. Nat Rev Immunol 5: 435-445, 2005

37. Karin M and Greten FR: NF-kappaB: linking inflammation and immunity to cancer development and progression. Nat Rev Immunol 5: 749-759, 2005.

38. Keutgens A, Robert I, Viatour P and Chariot A: Deregulated NF-kappaB activity in haematological malignancies. Biochem Pharmacol 72: 1069-1080, 2006.

39. Stoffel A: The NF-kappaB signalling pathway: a therapeutic target in lymphoid malignancies? Expert Opin Ther Targets 9: 1045-1061, 2005.

40. Salem K, Brown CO, Schibler J and Goel A: Combination chemotherapy increases cytotoxicity of multiple myeloma cells by modification of nuclear factor (NF)- $x \mathrm{~B}$ activity. Exp Hematol 41: 209-218, 2013.

41. Ni H, Ergin M, Huang Q, et al: Analysis of expression of nuclear factor kappa B (NF-kappa B) in multiple myeloma: downregulation of NF-kappa B induces apoptosis. Br J Haematol 115: 279-286, 2001

42. Bharti AC, Donato N, Singh S and Aggarwal BB: Curcumin (diferuloylmethane), down-regulates the constitutive activation of nuclear factor-kappa B and IkappaBalpha kinase in human multiple myeloma cells, leading to suppression of proliferation and induction of apoptosis. Blood 101: 1053-1062, 2003. 